\title{
Ownership Structure, Bank Capital and Bank Lending/Financing Behaviour in a Dual Banking System
}

\author{
Nor Faezah Ghazi Ahmad, Nor Aiza Mohd Zamil, Rohaida Basiruddin, Sarah Athirah Saruchi
}

\begin{abstract}
Credit supply in the market is crucial in order to ensure sustainable real production can survive in the market as well as to strengthen economic activity. Therefore, it is not surprising that when the financial crisis occurred in 2008 to 2009, policymakers continued to use a variety of mechanisms such that banks could continue to maintain their credit supply. Nevertheless, risk sharing based on the business model that was adopted by Islamic banks displayed different behaviour from the conventional banks. Based on prior studies, the stability of financing growth by Islamic banks as compared to lending growth of conventional banks showed the model used by Islamic banks was more capable of effectively withstanding the financial crisis. Therefore, research into the quality of lending and financing is important to understand the growth of bank lending and financing behaviour in the market. Hence, the main objective of this study is to review the effect of ownership structure, bank capital and bank lending including financing behaviour in Islamic versus conventional banks. In addition, this study proposes a conceptual framework to further comprehend the decisions made in undertaking ownership structure, bank capital and lending in the dual banking system..
\end{abstract}

Keywords: Bank Lending; Ownership Structure; Bank Capital; Islamic banks; Conventional banks.

\section{INTRODUCTION}

Over the last few years, state governments, especially the central bank, and regulators have taken proactive and serious action to improve supervisory efficiencies and expand the level of financial intermediaries [1]. This action was taken to empower a more resilient financial system to protect financial institutions from experiencing financial shock. Strengthening capital, increasing liquidity, and engaging in the real economy is a strategy used by financial institutions to enhance the capabilities of banks [2]. The global financial crisis concentrated attention on the important role of the banks as a money supply to stabilise the financial flow in the market. The global financial crisis that took place in 2008 to 2009 had a huge impact on the global economy under such economic pressures [3]. The result of this situation indicated that there is a weakness in the existing global financial system where well-established banks have also been affected and in some cases have become bankrupt. Furthermore, the increase in the default

Revised Manuscript Received on April 19, 2019.

Nor Faezah Ghazi Ahmad, Azman Hashim International Business School, Universiti Teknologi Malaysia, 54100 Malaysia.

Nor Aiza Mohd Zamil, Azman Hashim International Business School, Universiti Teknologi Malaysia, 54100 Malaysia.

Rohaida Basiruddin, Azman Hashim International Business School, Universiti Teknologi Malaysia, 54100 Malaysia.

Sarah Athirah Saruchi, Azman Hashim International Business School, Universiti Teknologi Malaysia, 54100 Malaysia. risk in banks made the problem even more serious [4]. This eventually indicated the fragility of regulation and supervision which stood as the crucial point leading to the crisis [5],[6]. Practicing Shariah compliance supervised by a Shariah Supervisory Board (SSB) in every business operation, allowed Islamic banks to reduce any risks involved, including reducing credit risk during the financial crisis [7]. Therefore, bankers and financial experts found that the Islamic finance system was the best alternative to solving this problem where Islamic banks continued to maintain their stability and resilience during the financial crisis [8],[9].

Past studies have found that the political pattern of a country affects the stability of the economy [10],[11],[12]. Therefore, it can be assumed that the government of each country has an influence on the activities of governmentowned entities including government-owned banks. Lending provided by banks can be used as investment capital to engage in the real economy. However, lending by these banks stems from the existing capital adequacy to protect the banks from the occurrence of credit risk [13]. Hence, bank lending is one of the important global issues, where it plays a crucial function not only for corporate business but also for the development of the economy in general [14]. Lending is a financial source that can mitigate the burden of financial difficulties faced, especially for small and medium sized firms that often experience difficulty in obtaining credit. Lending provided by the banks is vital to enable firms to run their projects and this activity can improve the economic development of the country in general [15]. Therefore, lending provided by government-owned banks or foreign-owned banks serves as an important tool to address the problem of credit shortage in the market as well as to improve the economy of the country.

The bank ownership structure is determined by the percentage share of ownership either owned by the government or foreign ownership. This ownership has a different impact and influence on bank lending behaviour whether before or during the financial shock. Governmentowned banks play an important role in economic stability and recovery during the global financial crisis [11]. By the government holding majority shares in the banks, it makes it easier for the government to implement policies and regulations to mitigate an economic downturn. Numerous studies have highlighted government-owned banks increasing their total loans during the crisis in order to 
stabilise the economy [11],[16]. The increase in bank lending during a crisis is important to ensure the credit supply in the market is sufficient for financing potential projects as well as improving the economy. However, there is an argument concerning the efficiency and integrity of government-owned banks, especially related to the distribution of financial resources. The 'political view' says that politicians use government-owned banks as a tool for their own benefit [17]. This action has resulted in resource misallocation (giving bribes to the voters) and inefficiencies in the economy [18]. In addition, criticism has been made of foreign bank access to host countries where foreign-owned banks can weaken the stability of domestic owned banks. Fierce competition between these two types of bank can reduce the number of customers and reduce the profitability of local banks. However, both banks' ownership is very important to ensure that the credit supply in the market is sufficient to serve as an alternative source to cover the financial difficulties faced.

Therefore, the purpose of this study is to review the changes in bank ownership and its impact on the ownership structure between the domestic and foreign banks (government-owned banks) and the foreign-owned banks with regard to Islamic banks and conventional banks.

\section{LITERATURE REVIEW}

This study began with the background of Islamic banking to determine the emphasis of the theory used as a tool for contributing to stability and to review the comparative arguments of conventional banks.

\section{A. Islamic Banking}

The swift development and growth of Islamic banking over recent years has become a vital part of the financial system in most countries as shown in Fig 1. The expansion of Islamic Financial Institutions (IFIs) assets during the global financial crisis has grown significantly higher in 2011 at $19 \%$ and $21 \%$ in 2012 as compared to less than $10 \%$ for conventional banking [19]. The necessity for Islamic banking has strengthened especially after the global financial collapse that took place during the financial crisis. The crisis has proven the fragility of the interest-based debt regime practiced by the conventional banking system. Instead, the emergence of Islamic banking has been seen to be more stable and resilient. The concept of profit-loss sharing (PLS) practiced by Islamic banking in its deposit products allowed the Islamic banks to survive during the financial crisis [20],[8],[21]. The interest-based approach adopted by the conventional banking system can be seen as an injustice as it allows the financier to earn interest without engaging in any actual productive activities.

According to the recent meaning of 'Islamic banking' as mentioned within the financing and funding system this is based on Islamic law (Shariah) and the principles of Islamic jurisprudence (Fiqh) [22]. The prohibition of interest ( $r i b a$ '), uncertainty (gharar), and gambling (mysir) are the key features of the Islamic banking operation where all the transactions must be involved in real activities [23]. Shariah, which is Islamic law, is the backbone of a PLS business model which distinguishes between the Islamic banking system and the conventional banking systems.
Therefore, in order to demonstrate their compliance with Shariah principles, Islamic banking ensures that all activities are carried out based on the PLS and are involved in real sector linkage.

The uniqueness of the Islamic capital structure [24] can be seen through two fundamental aspects: the conventional debt restriction in the form of a new liability, namely the existence of the Profit Sharing Investment Account (PSIA) which is fundamental to PLS. This fundamental emphasises risk and profit sharing between contracting parties [25]. In other words, both parties are involved and responsible for the contract made. Therefore, the profits earned from PSIA will be shared in accordance with the accepted ratio. The bank as a corporate body is always cautious and efficient in managing its investment to provide stable returns and profitability for its depositors.

\section{B. Ownership Structure}

Ownership essentially relates to a package of privileges and it can be private or public. Montias, 1976 on the structure of economic systems in Yale University press, expresses 'ownership' as the right of an individual to control his possessions exclusively and attempt to influence the actions and decisions of an object or service either to use it or to dispose of it for personal purposes [26]. Rights comprise the right to own, to influence, to employ, to eliminate others, to secure income, to protection, and to receive recompense if damaged. On a wider scope, the ownership structure refers to

the percentage of shares owned by individuals, government, and private investors in one organisation [27],[12]. [28] classified two types of ownership for a wider range, namely foreign ownership and domestic ownership. Therefore, the largest ownership shareholding will have the right to make decisions and rules within a firm. Usually, private ownership of a domestic bank is formed through a joint venture between local banks and foreign banks where the former has a greater ownership and it is able to control entities. Large domestic private banks are generally allowed to take part in foreign exchange while private-small domestic banks are not permitted to employ foreign exchange to avoid the effects of different bank efficiencies, whereas government-owned banks are owned by the federal government or local government.

The ownership structure is important to determine the power control over a firm as well as to determine the pattern of governance and behaviour of a firm [29]. In the context of banking institutions, the most common ownership is classified by two ownership types, namely 1) a domestic-owned bank which focuses on a governmentowned bank and, 2) a foreign-owned bank which has an ownership of share of $50 \%$ or more by a government or foreign investor [30]. These two types of possession play different roles such as in a government-owned bank which is responsible to promote the recovery and stability of the economy especially during a financial crisis by providing resources and also helping to boost economic development 
[10],[11],[16]. On the other hand, a foreign-owned bank can supply capital, technical skill, product innovation (mostly in developing countries) and improve the efficiency of the banking sector [32]. Hence, the ownership structure of the bank is important to ensure sufficient supply of credit in the market and the role of each type of bank can be used properly especially during a global financial crisis.

\section{Trend and competition in Ownership structure}

The presence of bank ownership as either a domesticowned bank or a foreign-owned bank affects each other. Previously, the ownership structure of the banking sector in developing countries indicated a rise in the contribution of foreign-owned banks, although there was a drop in government-owned banks. The share of bank assets held by foreign banks in developing countries increased from $16 \%$ in 1995 to $50 \%$ in 2008, whereas the government bank ownership declined from $40 \%$ to $17 \%$ between 1995 and $2008^{1}$. In contrast, the share of assets held by foreign-owned banks in developed countries increased from $15 \%$ to $43 \%$ whereas the government-owned banks declined $36 \%$ to $10 \%$ between 1995 and 2008. The increase in foreign bank contribution in the banking industry was inspired by the collective indication that the presence of foreign banks would provide various benefits for developing countries, particularly with respect to competition and productivity [32],[33]. In addition, countries with a higher level of during the crisis [34][35]. This indicated that the 2008 financial crisis was not only causing a bad time in the U.S. as a crisis originator, but also in those countries with a high level of foreign bank penetration.

However, the reduction of the shared assets by foreign banks was moderate and temporary. In 2012 to 2013 the share of assets by foreign banks rebounded and improved mainly in European and Middle Eastern countries. Foreignowned banks nowadays are the leading player in the banking systems around the world as shown in Fig. 2.1, as compared to government-owned banks that only became key players in several countries as shown in Fig. 2.2.

\section{Capital Growth and Bank Lending}

Other than the ownership structure, bank capital also has an influence on bank lending behaviour during such a crisis. References [36],[37] highlighted that banks that had a large amount of Tier 1 and Tier 2 capital and deposits were able to survive during the financial crisis. Moreover, according to the rules set out under Basel I, each bank is required to hold $8 \%$ of the Tier1 capital against the total risk-weighted assets. However, in Basel II, the capital regulation allowed banks to reduce their capital requirement against assets on their balance sheet (e.g. triple A rating of the securitised mortgage). Due to capital inadequacy, many of the financial institutions did not have enough of a financial cushion to support the losses from the loan defaults. Thus, banks had to cut their lending supply due to a liquidity shortage. From another aspect, [37] found that a bank with a strong balance sheet could reduce their lending during a crisis. This implied that banks with better access to deposits and/or less dependence on wholesale funding may survive during an foreign bank penetration experienced lower credit growth

economic downturn [33],[37],[38]. Other than that, shortterm wholesale funding has been found to be a key determinant in prompting systematic risk. The usage of wholesale funding is good for a bank as a core deposit supplement [38]. All in all, capital quality is highly dependent on the risk-taking behaviour and credit decisions of a bank. However, each bank has its own principles and strategies to deal with this issue.

\section{CONCEPTUAL FRAMEWORK}

The conceptual framework of this study has been developed based on the discussion in Section II above. Generally, bank lending growth are influenced by the ownership structure and capital growth. Ownership structure is classified into two types, namely domestic-owned (government-owned bank) banks and foreign-owned banks whereas capital divided by two types; Tier 1 and Tier 2 . Each of these types of bank plays

an important role in improving the economic development of the country. Therefore, both of these factors are important to ensure the credit supply in the market flows smoothly. The con eptual framework of this study is shown in Fig. 3.

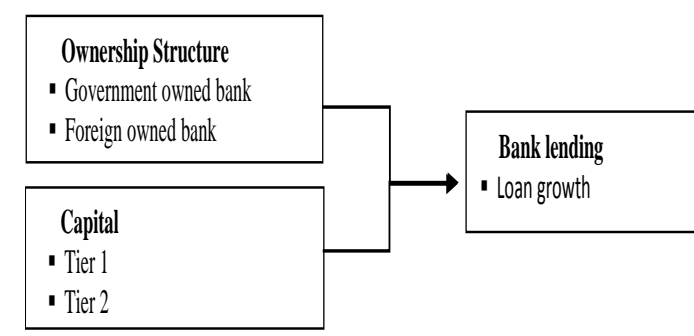

Fig. 3: Conceptual framework

Ownership structure, bank capital and lending/financing behaviour of dual banking systems

\section{CONCLUSION AND FUTURE RESEARCH}

This study discusses the relationship of the ownership structure, bank capital and bank lending/financing in banking institutions. Bank behaviour usually varies depending on the lending undertaking which depends on the funding structure of the bank especially during liquidityshock periods [38]. Likewise, reference [39] stressed that typically a financial crisis reduces the supply of lending resources in the market which limits the ability of firms to borrow. The global financial crisis that took place as a result of the worldwide financial downturn of interest-based systems has proven the fragility of the applied financial system which is now seen as inefficient and not protected from the onset of losses. However, Islamic banks appear to be stable and resilient and are found to practicing a profitloss-sharing system. As this paper is a conceptual paper, then future studies can be expanded by including empirical data for both Islamic banks and conventional banks in which the result can be compiled in a cross-country big data set. Such empirical data could be used to validate the proposed conceptual framework to determine the extent to which 
ownership structure affects bank lending and capital growth for the given three sets of data i.e. before the crisis, during the crisis, and after the crisis

\section{APPENDIX}

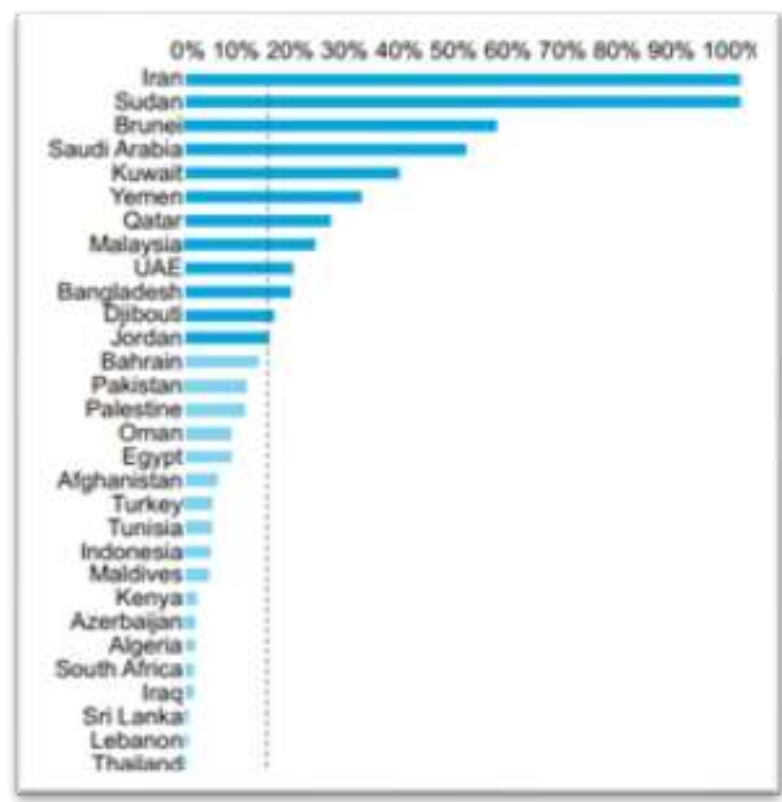

Fig. 1: The share of Islamic Banking in Total Banking Assets by Jurisdiction (2016)

Source: Islamic Financial Services Board, (2017).

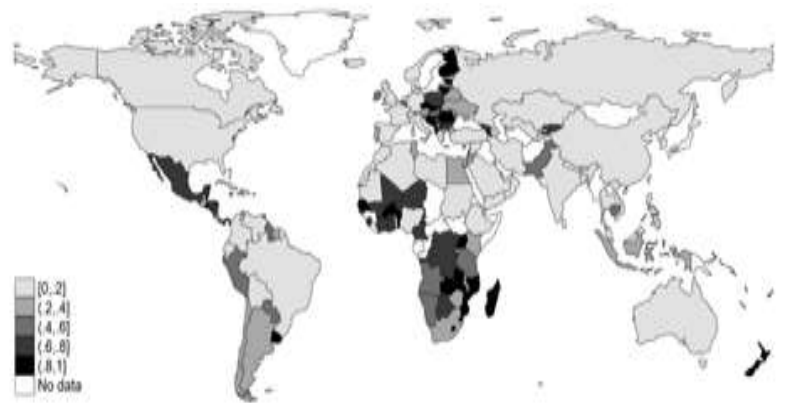

Figure 2.1 Share of assets owned by foreign banks, 2012 to 2013

Sources: Bank Regulation and Supervision surveys (World Bank).

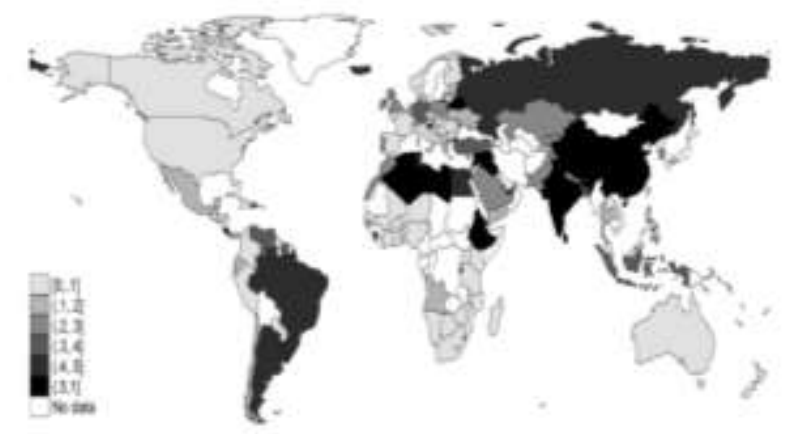

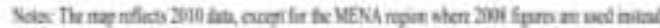

Fig 2.2 Share of assets owned by government banks, 2010

Sources: Bank Regulation and Supervision surveys (World Bank); [40]

\section{REFERENCES}

1. Kapan, T., \& Minoiu, C. (2018). Balance Sheet Strength and Bank Lending: Evidence from the Global Financia Crisis. Journal of Banking and Finance.

2. Ibrahim, M. H. (2019). Capital regulation and Islamic banking performance: Panel evidence. Bulletin of Monetary Economics and Banking, 22(1), 47-68.

3. Salachas, E. N., Laopodis, N. T., \& Kouretas, G. P. (2017). The bank-lending channel and monetary policy during pre- and post-2007 crisis. Journal of International Financial Markets, Institutions and Money, 47, 176-187.

4. Louhichi, A., \& Boujelbene, Y. (2017a). Bank capital, lending and financing behaviour of dual banking systems. Journal of Multinational Financial Management, 41(september 2008), 61-79

5. Hogan, T. L. (2015). Capital and risk in commercial banking: A comparison of capital and risk-based capital ratios. Quarterly Review of Economics and Finance.

6. Ibrahim, M. H. (2019). Capital regulation and Islamic banking performance: Panel evidence. Bulletin of Monetary Economics and Banking, 22(1), 47-68.

7. Grassa, R. (2015). Shariah supervisory systems in Islamic finance institutions across the OIC member countries: An investigation of regulatory frameworks. Journal of Financial Regulation and Compliance.

8. Farooq, M., \& Zaheer, S. (2015). Are islamic banks more resilient during financial panics? Pacific Economic Review.

9. Ghassan, H. B., \& Fachin, S. (2016). Time series analysis of financial stability of banks: Evidence from Saudi Arabia. Review of Financial Economics.

10. Brei, M., \& Schclarek, A. (2013). Public bank lending in times of crisis. Journal of Financial Stability, 9(4), 820 830.

11. Brei, M., \& Schclarek, A. (2015). A theoretical model of bank lending: Does ownership matter in times of crisis? Journal of Banking and Finance, 50, 298-307.

12. Jackowicz, K., Kowalewski, O., \& Kozłowski, Ł. (2013). The influence of political factors on commercial banks in Central European countries. Journal of Financial Stability, 9(4), 759-777.

13. Chen, Y. S., Chen, Y., Lin, C. Y., \& Sharma, Z. (2016) Is there a bright side to government banks? Evidence from the global financial crisis. Journal of Financial Stability, 26, 128-143.

14. Malede, M. (2013). Determinants of Commercial Banks Lending: Evidence from Ethiopian Commercial Banks. Asian Journal of Empirical Research, 3(8), 933-943.

15. Sanfilippo-Azofra, S., Torre-Olmo, B., Cantero-Saiz, M., \& López-Gutiérrez, C. (2017). Financial Development and Banks' Loan Supply in Developing Countries. Journal of Macroeconomics, 55(April 2017), 215-234.

16. Coleman, N., \& Feler, L. (2015). Bank ownership, lending, and local economic performance during the 2008-2009 financial crisis. Journal of Monetary Economics, 71, 50-66.

17. Pan, X., \& Tian, G. G. (2017). Political connections and corporate investments: Evidence from the recent anticorruption campaign in China. Journal of Banking and Finance.

18. Shleifer, A., \& Vishny, R. W. (2006). Politicians and Firms. The Quarterly Journal of Economics.

19. Popper, N. (2013). Islamic banks, stuffed with cash, explore partnership in West. The New York Times, Dec 25th, 2013.Price Waterhouse Cooper. (2011). Shariah Audit: industry insights. PWc Report. Rahman 
20. Belanès, A., Ftiti, Z., \& Regaïeg, R. (2015). What can we learn about Islamic banks efficiency under the subprime crisis? Evidence from GCC Region. Pacific Basin Finance Journal.

21. Othman, N., Abdul-Majid, M., \& Abdul-Rahman, A (2019). Determinants of Banking Crises in ASEAN Countries. Journal of International Commerce, Economics and Policy.

22. Farook, S., Hassan, M. K., \& Clinch, G. (2014). Islamic bank incentives and discretionary loan loss provisions. Pacific Basin Finance Journal, 28, 152-174.

23. Ibrahim, M. H., \& Rizvi, S. A. R. (2018). Bank lending, deposits and risk-taking in times of crisis: A panel analysis of Islamic and conventional banks. Emerging Markets Review.

24. Al- Deehani, T., Karim, R. A. A., \& Murinde, V. (2003). The capital structure of Islamic banks under the contractual obligation of profit sharing. International Journal of Theoretical and Applied Finance.

25. Duasa, J., Raihan Syed Mohd Zain, S., \& Tarek AlKayed, L. (2014). The relationship between capital structure and performance of Islamic banks. Journal of Islamic Accounting and Business Research.

26. Hunter, H. (1977). The Structure of Economic Systems By John Michael Montias. New Haven and London: Yale University Press, 1976. xii, 323 pp. Slavic Review.

27. Ferri, G., Kalmi, P., \& Kerola, E. (2014). Does bank ownership affect lending behavior? Evidence from the Euro area. Journal of Banking and Finance, 48(May), 194-209.

28. Shaban, M., \& James, G. A. (2018). The effects of ownership change on bank performance and risk exposure: Evidence from indonesia. Journal of Banking and Finance.

29. Jensen, M. C., \& Meckling, W. H. (1976). Theory of the firm: Managerial behavior, agency costs and ownership structure. Journal of Financial Economics, 3(4), 305-360

30. Cull, R., \& Martínez Pería, M. S. (2013). Bank ownership and lending patterns during the 2008-2009 financial crisis: Evidence from latin America and Eastern Europe. Journal of Banking and Finance, 37(12), 48614878.

31. Linda, G. (2004). Financial-Sector FDI and Host Countries: New and Old Lessons. NBER Working Paper.

32. Curi, C., Lozano-Vivas, A., \& Zelenyuk, V. (2015). Foreign bank diversification and efficiency prior to and during the financial crisis: Does one business model fit all? Journal of Banking and Finance.

33. Temesvary, J., \& Banai, A. (2017). The drivers of foreign bank lending in Central and Eastern Europe: The roles of parent, subsidiary and host market traits. Journal of International Money and Finance, 79, 157-173.

34. De Haas, R., \& Van Lelyveld, I. (2014). Multinational banks and the global financial crisis: Weathering the perfect storm? Journal of Money, Credit and Banking, 46(SUPPL.1), 333-364.

35. Ralph De Haas and Neeltje Van Horen. (2013). Running for the Exit? International Bank Lending During a Financial Crisis. Review of Financial Studies, 26(1), 244-285.

36. Beltratti, A., \& Stulz, R. M. (2012). The credit crisis around the globe: Why did some banks perform better? Journal of Financial Economics.

37. Ivashina, V., \& Scharfstein, D. (2010). Bank lending during the financial crisis of 2008. Journal of Financial Economics.

38. Jung, H., \& Kim, D. (2015). Bank funding structure and lending under liquidity shocks: Evidence from Korea. Pacific Basin Finance Journal.

39. Zeitun, R., Temimi, A., \& Mimouni, K. (2017). Do financial crises alter the dynamics of corporate capital structure? Evidence from GCC countries. Quarterly Review of Economics and Finance.

40. Cull, R., Martinez Peria, M., \& Verrier, J. (2017). Bank Ownership: Trends and Implications. IMF Working Papers.

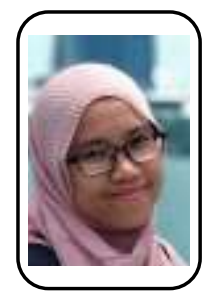

\section{AUTHORS PROFILE}

First Author Nor Faezah Ghazi Ahmad is a thirdyear $\mathrm{PhD}$ student at Azman Hashim Internationa Business School, Kuala Lumpur, Malaysia. She received a bachelor degree in Financial Services (Marketing) from Universiti Sains Islam Malaysia, Negeri Sembilan, Malaysia and a master's degree in Islamic Economy (Banking) from Universiti Kebangsaan Malaysia. She is interested in bank lending, governance, and any subjects related to Islamic banking

and finance.

Second Author Nor Aiza Mohd Zamil is a senior lecturer at Azman Hashim International Business School, Kuala Lumpur, Malaysia. She earned her master's degree from International Islamic University Malaysia and she successfully received her doctorate degree from Cardiff University, United Kingdom. She is interested in accounting, finance and any subjects related to banking.

Third Author Rohaida Basiruddin holds a PhD in Accounting and Finance from Durham University Business School, UK and currently teaches accounting subject for MBA and DBA programs. She has been involved in academic research for the last ten years and supervised $\mathrm{PhD}$ students for the last seven years. Her research interests are corporate governance, audit, earnings management and Islamic banking.

Fourth Author Sarah Athirah Saruchi is a third-year PhD student at Azman Hashim International Business School, Kuala Lumpur, Malaysia. She received a bachelor degree in Shariah (Islamic Economy and Banking) from Yarmouk University of Jordan and a master's degree in Islamic Economy (Banking) from Universiti Kebangsaan Malaysia. She is interested in intellectual capital, corporate governance and any subjects related to banking and Islamic economy. 